\title{
SENTIMEN ANALISIS COVID-19 DENGAN METODE PROBABILISTIC NEURAL NETWORK DAN TF-IDF
}

\author{
Ina Najiyah ${ }^{1}$, Ifani Haryanti ${ }^{2}$ \\ 1 Universitas Adhirajasa Reswara Sanjaya \\ e-mail: inajiyah@ars.ac.id \\ ${ }^{2}$ Universitas Adhirajasa Reswara Sanjaya \\ e-mail: ifani@ars.ac.id
}

\begin{abstract}
Abstrak
Penelitian ini bertujuan melakukan sentiment analysis tentang corona virus pada kegiatan sehari hari yang diunggah di facebook, Twitter dan Instagram dengan output yaitu 3 class:positif, negative dan netral. Metode yang dipilih adalah metode klasifikasi Probabilistic Neural network. Sebelum melakukan klasifikasi, praprocessing pada penelitian ini meliputi tokenizasi, normalisasi, menghilangkan emoticon, Convert Negasi, Stopword removal sertaTF-IDF. dataset yang digunakan berjumlah 1177 dataset dengan pembagiannya yaitu 560 dataset positif, 355 dataset negative dan 262 dataset netral. Program dirancang menggunakan Bahasa pemrograman python dengan beberapa library seperti keras, tensorflow dan pandas. User interface dibuat berbasis android. Akurasi yang didapatkan pada pelatihan menggunakan Probabilistic Neural network sebesar $89 \%$. Hasil pengujian adalah penelitian ini mampu melakukan sentiment analysis dengan kesalahan sebesar $11 \%$ dilihat dari confussion matrix.
\end{abstract}

Kata Kunci: analisis sentimen, covid19, neural network.

\begin{abstract}
This study aims to conduct a sentiment analysis about the corona virus in daily activities uploaded on Facebook, Twitter and Instagram with the output of 3 classes: positive, negative and neutral. The method chosen is the Probabilistic Neural network classification method. Prior to classification, preprocessing in this study includes tokenization, normalization, removing emoticons, Negation Convert, Stopword removal and TF-IDF. The dataset used is 1177 datasets with the division of 560 positive datasets, 355 negative datasets and 262 neutral datasets. The program is designed using the Python programming language with several libraries such as Keras, Tensorflow and Pandas. The user interface is based on android. The accuracy obtained in training using a Probabilistic Neural network is $89 \%$. The test result is that this study is able to perform sentiment analysis with an error of $11 \%$ seen from the confussion matrix.
\end{abstract}

Keywords: Sentimen Analysis, Covid19, Neural network.

\section{Pendahuluan}

Corona COVID-19 merupakan sebuah virus yang muncul pada tahun 2019 dan bermula di china(Amelia, 2020). Penyebaran virus ini dianggap sangat cepat dan melebar luas ke seluruh Negara salah satunya Indonesia(Kasmad, 2020). Munculnya virus covid 19 ini mendapat banyak tanggapan dan opini yang dikemukakan oleh masyarakat Indonesia pada kehidupan sehari hari khususnya pada platform digital atau media social seperti facebook, twitter dan instagram. Tanggapan dan opini yang dikemukakan melalui social media tersebut dapat menjadi pengaruh kepada masyarakat yang membacanya sehingga perlu dilakukan penyaringan opini tersebut agar tidak salah menerima informasi dan tidak salah menilai apakah opini tersebut bersifat negative, positive atau netral salah satu caranya adalah melakukan sentiment analysis. Sentimen analisis adalah riset komputasional dari opini sentiment dan emosi yang diekspresikan secara tekstual(Zulfa \& Winarko, 2017). sentiment analysis pada data twitter pernah dilakukan 
menggunakan metode RNN(Nemes \& Kiss, 2021), penelitian ini menghasilkan akurasi sebesar $75 \%$ dari 1100 dataset. Hal ini dikarenakan proses yang dilakukan hanya Tokenizing dan filtering sehingga masih banyak data atau teks yang tidak di clean secara baik.

Selain itu pernah juga dilakukan menggunakan metode naïve bayes dengan dataset yaitu tentang pembelajaran daring dengan akurasi 72\% (Samsir et al., 2021). Hal ini disebabkan karena fuzzy logic cara kerjanya lebih bagus terhadap data berupa angka dan dataset yang kecil. Dari penelitian sebelumnya, akurasi masih terbilang cukup tetapi kurang baik sehingga perlu diuji menggunakan metode lain yang menghasilkan akurasi lebih baik. dataset yang dipakai pada penelitian sebelumnya pun terbilang masih sedikit. Neural network merupakan metode yang sering digunakan dalam dataset gambar maupun teks dan menghasilkan akurasi baik seperti pada kasus analisis sentiment mengenai sarana dan transportasi mudik tahun 2019 (Pertiwi, 2019), selain itu penelitian lain menggunakan metode ini untuk analisis sentimen usaha waralaba berdasarkan data twitter (Mardiana et al., 2019), selain itu pernah juga dilakukan untuk Analisis Sentimen Pada Bpjs Kesehatan (Faturohman et al., 2020), penelitian lain menggunakan metode ini untuk Analisis Sentimen Terhadap Review Aplikasi E-commerce (Khatami et al., 2020), dan pernah juga dilakukan recurrent neural network (rnn) dengan long short term memory (Istm) untuk analisis sentimen data instagram(Cahyadi et al., 2020). Pada penelitian ini sentiment analysis dilakukan menggunakan metode Probabilistic Neural network dan metode TF-idf. TF-idf ditambahkan guna dapat melakukan representasi teks sehingga proses klasifikasi lebih akurat.

TF-idf dapat merepresentasi teks lebih baik dibandingkan sckit learn dikarenakan cara kerjanya tepat untuk data yang berupa teks, Data yang digunakan pada penelitian ini adalah data opini mengenai covid 19 yang ada pada facebook, twitter dan instagram. Data yang digunakan merupakan data public yaitu yang diambil dari kaggle, dan uci repository. Tujuan dari penelitian ini yaitu untuk melakukan sentiment analysis dan mengklasifikasikan opini mengenai covid19 menjadi tiga class yatu class positif, negative dan netral..

\section{Metode Penelitian}

Sistem yang akan dibangun dibagi menjadi dua tahapan utama. Pertama terdapat proses pelatihan dan proses pengujian.

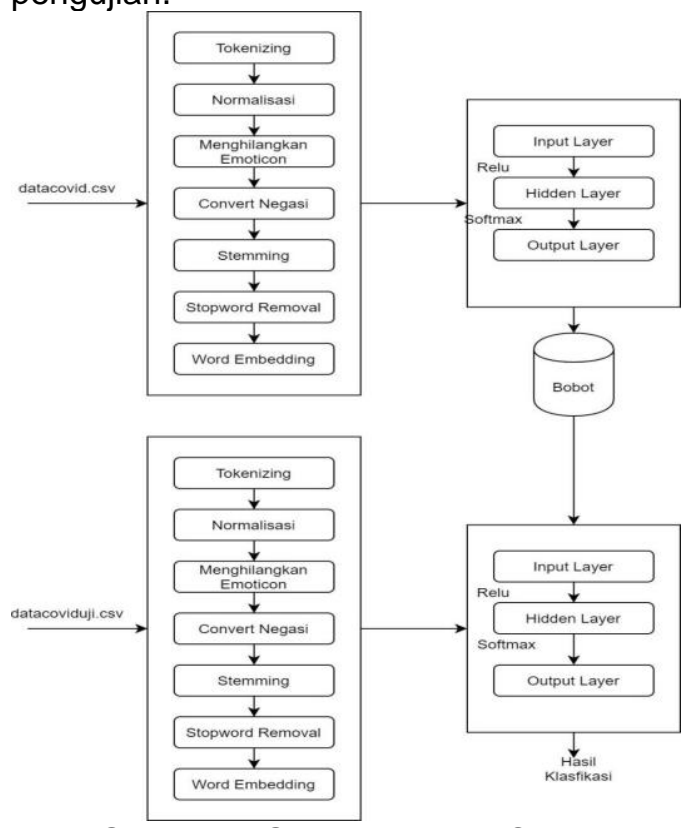

Gambar 1 Gambaran Alur Sistem

\section{Hasil dan Pembahasan \\ 3.1 Analisis Data Masukan}

Berdasarkan analisis masalah yang telah dibahas sebelumnya, maka untuk menyelesaikan permasalahan tersebut, tahap awal yang perlu dilakukan adalah mengumpulkan data-data untuk dijadikan dataset. Data yang digunakan diambil dari social media seperti Twitter Facbook dan Instagram. Data yang didapatkan berupa kalimat yang berisi status, caption serta komentar orang terhadap pandemic Covid 19 bisa berupa deskripsi hingga ungkapan emosi. Pada kalimat tersebut berisi kata, angka, tanda baca hingga emoticon. Untuk polaritas yang mendominasi hanyalah positif dan negatif, karena data yang memiliki polaritas netral sangat sedikit sehingga polaritas yang digunakan hanya positif dan negative saja. Berikut merupakan contoh dataset yang ditunjukkan pada Tabel 1 .

Dari beberapa contoh pada Tabel 1 dapat disimpulkan bahwa setiap status, caption serta komentar berbeda beda. Hal tersebut bisa berdampak pada tingkat akurasi. Seperti pada contoh ulasan ke 4 penggunaan tanda baca tidak sesuai penempatan yang sebenarnya. Pada proses klasifikasi teka, tanda baca tidak digunakan dalam proses sehingga biasanya dihapus. Penggunaan emoticon seperti pada contoh 
ulasan pertama dan kedua di atas, sangat berpengaruh terhadap penentuan polaritas. Contoh pada ulasan pertama penggunaan emoticon kurang tepat penggunaanya sehingga emoticon tersebut akan dihilangkan atau di abaikan. Agar sistem dapat mengenali setiap kata maka diperlukan pemisahan tiap kata pada sebuah kalimat. Sehingga kata-kata yang telah terpisah akan digunakan untuk fitur. Hasil pemisahan kata tidak bisa langsung digunakan untuk proses klasifikasi, setiap penulisan akan diperiksa dan diubah ke kata yang benar. Atau jika menemukan kata yang tidak baku akan diubah ke dalam kata baku. Agar sistem dapat mengenali setiap kata negatif maka diperlukan penggabungan kata pada sebuah kalimat. Pada contoh ulasan no 2 kata "tidak" dan kata "selamat" akan digabungkan sehingga kata tersebut bermakna negatif pada sistem. Contoh kata kata negasi adalah "tidak", "jangan", "bukan" dan lain sebagainya. Pada proses klasifikasi pun tidak seluruhnya kata digunakan pada proses klasifikasi, hanya beberapa kata yang bermakna yang sebaiknya diproses, agar fitur yang dihasilkan tidak terlalu banyak. Pada contoh ulasan ketiga di atas terdapat kata umum seperti "ini" dan "jadi" yang biasanya muncul dalam jumlah besar dan dianggap tidak memiliki makna, sehingga kata tersebut akan dihapus. Setelah menyisakan kata-kata yang memiliki makna, maka setiap kata yang berimbuhan seperti pada ulasan kedua dan keempat di atas akan diubah ke dalam bentuk kata dasar, agar tidak menghasilkan dimensi data yang terlalu besar. Oleh karena itu diperlukan tahap preprocessing untuk mengubah dataset tersebut agar siap digunakan untuk inputan pada system yang dibangun. Analisis data masukan dilakukan dengan tujuan untuk mendapatkan nilai-nilai dari data masukan untuk kemudian digunakan pada proses klasifikasi dengan metode Probabilistic Neural network dan TF-idf. Data masukan yang digunakan pada penelitian ini adalah data text yang diambil dari social media mengenai covid19. Pada penelitian ini, fitur yang digunakan adalah text Bahasa Indonesia. Text atau kalimat tersebut nantinya akan dilakukan Tokenizing, stemming, dan representasi text sebelum dilakukan klasifikasi. Berikut merupakan jumlah dataset yang diambil dari social media dengan 3 class yaitu class positif, negatif dan netral.

\begin{tabular}{|l|l|l|}
\hline No & Tabel 1. Dataset & Polaritas \\
\hline 1 & $\begin{array}{l}\text { Seneng banget gue } \\
\text { dengan covid19 ini jadi } \\
\text { makin banyak waktu } \\
\text { sama keluarga, gak } \\
\text { sibuk dengan urusan } \\
\text { masing-masing XD }\end{array}$ & Positif \\
\hline 2 & $\begin{array}{l}\text { Coba kalian bayangin, } \\
\text { ibu melahirkan disuruh } \\
\text { rapid dulu, keburu } \\
\text { anaknya tidak selamat }\end{array}$ & Negatif \\
\hline 3 & $\begin{array}{l}\text { Angka Covid tembus } \\
\text { 1jt.... yaaampuuun } \\
\text { parah banget }\end{array}$ & Negatif \\
\hline
\end{tabular}

\subsection{Proses Pelatihan \\ Pra proses Data}

Setelah mendapatkan data latih yang bersumber dari twitter, facebook dan Instagram yang berisi tema covid19. Maka data latih tersebut akan dijalankan guna membangun program analysis sentiment yang menghasilkan tiga kelas yaitu positif, negatif dan netral. Adapun diantaranya data latih sebagai berikut:

\begin{tabular}{|l|l|l|}
\hline No & Tabel 2. Tabel Data Latih & Polaritas \\
\hline 1 & $\begin{array}{l}\text { Seneng banget gue } \\
\text { dengan covid19 ini jadi } \\
\text { makin banyak waktu sama } \\
\text { keluarga, gak sibuk dengan } \\
\text { urusan masing-masing XD }\end{array}$ & Positif \\
\hline 2 & $\begin{array}{l}\text { Coba kalian bayangin, ibu } \\
\text { melahirkan disuruh rapid } \\
\text { dulu, keburu anaknya tidak } \\
\text { selamat }\end{array}$ & Negatif \\
\hline
\end{tabular}

Preprocessing dilakukan untuk mengurangi noise dan menyeragamkan data supaya memudahkan proses pelatihan dan proses pengujian. Adapun tahapan preprocessing yang akan dilakukan yaitu Tokenizing, normalisasi, menghilangkan emoticon, stemming, dan Stopword removal. Gambaran umum tahap preprocessing dapat dilihat pada Gambar 2. 


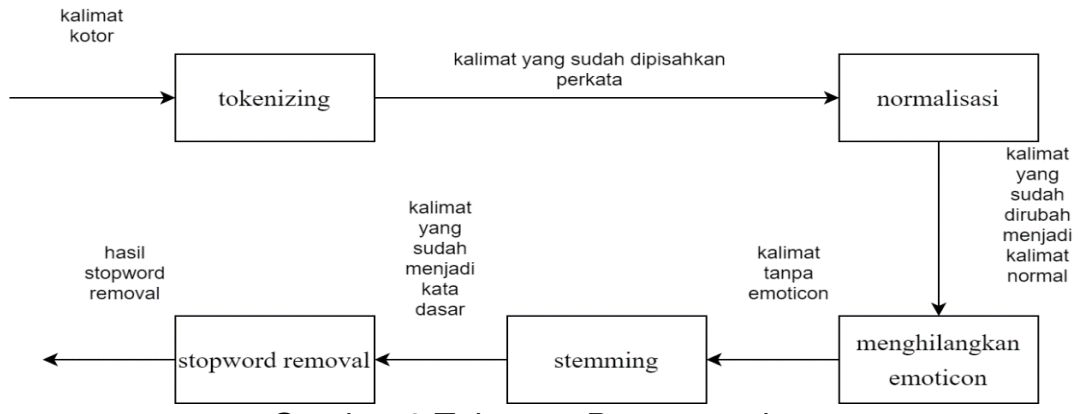

Gambar 2 Tahapan Preprocessing

\section{Tokenizing}

Tokenisasi adalah proses untuk membagi teks yang dapat berupa kalimat, paragraf atau dokumen, menjadi tokentoken/bagian-bagian tertentu. Proses pemisahan kalimat menjadi kata ini biasanya ditentukan dari sebuah delimiter. Delimiter atau pemisah dari setiap kata ini yakni spasi. Tokenizing dilakukan guna memudahkan proses klasifikasi dengan memisahkan kalimat menjadi per kata.

Berdasarkan data latih pada Tabel 2 hasil proses Tokenizing dapat dilihat pada Tabel 3 berikut.

Tabel 3. Hasil Tokenizing

\begin{tabular}{|l|l|l|}
\hline No & Isi Kalimat & Hasil Tokenizing \\
\hline 1 & & Seneng \\
& & banget \\
& & gue \\
& dengan \\
& Seneng & covid19 \\
banget gue & ini \\
& dengan & jadi \\
& covid19 ini & makin \\
& jadi makin & banyak \\
& banyak & waktu \\
& waktu & sama \\
& sama & keluarga, \\
& keluarga, & gak \\
& gak sibuk & sibuk \\
& dengan & dengan \\
& urusan & urusan \\
& masing- & masing-masing \\
& masing XD & XD \\
\hline 2 & & Coba \\
& & kalian \\
& bayangin, \\
& Coba & ibu \\
& kalian & melahirkan \\
bayangin, & disuruh \\
ibu & rapid \\
melahirkan & dulu, \\
disuruh & keburu \\
& rapid dulu, & anaknya \\
keburu & tidak \\
anaknya & selamat \\
tidak & \\
selamat & \\
\hline
\end{tabular}

\section{Normalization}

Proses ini merupakan proses dimana mengubah kata yang tidak sesuai dengan EYD menjadi sesuai dengan EYD. Bertujuan untuk menormalkan kalimat sehingga kalimat gaul menjadi normal (Adiyasa, sehingga bahasa gaul tersebut dapat dikenali sebagai bahasa yang sesuai dengan $\mathrm{KBBI}$ harus dilakukan untuk normalisasi kalimat adalah:

a. Meregangkan tanda baca (punctuation) dan symbol selain alphabet, lalu mengubah kata tidak baku menjadi baku. Contoh tahap ini sebagai berikut:

Tabel 4. Hasil Normalisasi

\begin{tabular}{|c|c|c|}
\hline No & Isi Kalimat & Hasil Normalisasi \\
\hline 1 & $\begin{array}{l}\text { Seneng } \\
\text { banget } \\
\text { gue } \\
\text { dengan } \\
\text { covid19 } \\
\text { ini } \\
\text { jadi } \\
\text { makin } \\
\text { banyak } \\
\text { waktu } \\
\text { sama } \\
\text { keluarga } \\
\text { gak } \\
\text { sibuk } \\
\text { dengan } \\
\text { urusan } \\
\text { masing-masing } \\
\text { XD }\end{array}$ & $\begin{array}{l}\text { Senang } \\
\text { banget } \\
\text { saya } \\
\text { dengan } \\
\text { covid19 } \\
\text { ini } \\
\text { jadi } \\
\text { semakin } \\
\text { banyak } \\
\text { waktu } \\
\text { dengan } \\
\text { keluarga } \\
\text { tidak } \\
\text { sibuk } \\
\text { dengan } \\
\text { urusan } \\
\text { masing } \\
\text { masing } \\
\text { XD }\end{array}$ \\
\hline 2 & $\begin{array}{l}\text { Coba } \\
\text { kalian } \\
\text { bayangin, } \\
\text { ibu } \\
\text { melahirkan } \\
\text { disuruh } \\
\text { rapid } \\
\text { dulu, } \\
\text { keburu } \\
\text { anaknya } \\
\text { tidak } \\
\text { selamat }\end{array}$ & $\begin{array}{l}\text { Coba } \\
\text { kalian } \\
\text { bayangkan } \\
\text { ibu } \\
\text { melahirkan } \\
\text { disuruh } \\
\text { rapid } \\
\text { dulu, } \\
\text { keburu } \\
\text { anaknya } \\
\text { tidak } \\
\text { selamat }\end{array}$ \\
\hline
\end{tabular}


b. Mengubah menjadi huruf kecil semua normalisasi kata .

Tabel 5. Hasil Normalisasi

\begin{tabular}{|c|c|c|}
\hline No & Isi Kalimat & Hasil Normalisasi \\
\hline 1 & $\begin{array}{l}\text { Senang } \\
\text { banget } \\
\text { saya } \\
\text { dengan } \\
\text { covid19 } \\
\text { ini } \\
\text { jadi } \\
\text { semakin } \\
\text { banyak } \\
\text { waktu } \\
\text { dengan } \\
\text { keluarga } \\
\text { tidak } \\
\text { sibuk } \\
\text { dengan } \\
\text { urusan } \\
\text { masing } \\
\text { masing } \\
\text { XD }\end{array}$ & $\begin{array}{l}\text { senang } \\
\text { banget } \\
\text { saya } \\
\text { dengan } \\
\text { covid19 } \\
\text { ini } \\
\text { jadi } \\
\text { semakin } \\
\text { banyak } \\
\text { waktu } \\
\text { dengan } \\
\text { keluarga } \\
\text { tidak } \\
\text { sibuk } \\
\text { dengan } \\
\text { urusan } \\
\text { masing } \\
\text { masing } \\
\text { xd }\end{array}$ \\
\hline 2 & $\begin{array}{l}\text { Coba } \\
\text { kalian } \\
\text { bayangkan } \\
\text { ibu } \\
\text { melahirkan } \\
\text { disuruh } \\
\text { rapid } \\
\text { dulu, } \\
\text { keburu } \\
\text { anaknya } \\
\text { tidak } \\
\text { selamat }\end{array}$ & $\begin{array}{l}\text { coba } \\
\text { kalian } \\
\text { bayangkan } \\
\text { ibu } \\
\text { melahirkan } \\
\text { disuruh } \\
\text { rapid } \\
\text { dulu, } \\
\text { keburu } \\
\text { anaknya } \\
\text { tidak } \\
\text { selamat }\end{array}$ \\
\hline
\end{tabular}

\section{Menghilangkan emoticon.}

Ketika sedang menulis status (tweet) seseorang kadang salah atau kurang tepat dalam penggunaan emoticon, entah disengaja atau tidak banyak yang melakukannya. Contohnya: Mereka hanya bisa memfitnah karena tidak bisa ketemu fakta buruk :), kata opini fitnah tapi emoticonnya senyum :), dengan begitu emoticon akan mengganggu dalam proses sentiment analysis tweet, jadi dalam proses ini emoticon dihapus atau diabaikan. Beberapa emoticon, feeling and sentiment dapat dilihat pada Gambar 3.

\begin{tabular}{ccc} 
Emoticon & Feeling & Sentiment \\
\hline$:):-)$ & Happy & Positive \\
$:(:-($ & Sad & Negative \\
$: D:-D$ & Very Happy! & Positive \\
D: D $=$ & Very Sad & Negative \\
$* * * * * * *$ & Fascinated & Positive
\end{tabular}

Gambar 3. Emotikon
Hasil proses menghilangkan emoticon seperti berikut:

Tabel 6. Hasil Menghilangkan Emoticon

\begin{tabular}{|c|c|c|}
\hline No & Isi Kalimat & $\begin{array}{l}\text { Hasil } \\
\text { Menghilangkan } \\
\text { Emotikon }\end{array}$ \\
\hline 1 & $\begin{array}{l}\text { Senang } \\
\text { banget } \\
\text { saya } \\
\text { dengan } \\
\text { covid19 } \\
\text { ini } \\
\text { jadi } \\
\text { semakin } \\
\text { banyak } \\
\text { waktu } \\
\text { dengan } \\
\text { keluarga } \\
\text { tidak } \\
\text { sibuk } \\
\text { dengan } \\
\text { urusan } \\
\text { masing } \\
\text { masing } \\
\text { XD }\end{array}$ & $\begin{array}{l}\text { senang } \\
\text { banget } \\
\text { saya } \\
\text { dengan } \\
\text { covid19 } \\
\text { ini } \\
\text { jadi } \\
\text { semakin } \\
\text { banyak } \\
\text { waktu } \\
\text { dengan } \\
\text { keluarga } \\
\text { tidak } \\
\text { sibuk } \\
\text { dengan } \\
\text { urusan } \\
\text { masing } \\
\text { masing }\end{array}$ \\
\hline 2 & $\begin{array}{l}\text { Coba } \\
\text { kalian } \\
\text { bayangkan } \\
\text { ibu } \\
\text { melahirkan } \\
\text { disuruh } \\
\text { rapid } \\
\text { dulu, } \\
\text { keburu } \\
\text { anaknya } \\
\text { tidak } \\
\text { selamat }\end{array}$ & $\begin{array}{l}\text { coba } \\
\text { kalian } \\
\text { bayangkan } \\
\text { ibu } \\
\text { melahirkan } \\
\text { disuruh } \\
\text { rapid } \\
\text { dulu, } \\
\text { keburu } \\
\text { anaknya } \\
\text { tidak } \\
\text { selamat }\end{array}$ \\
\hline
\end{tabular}

\section{Stemming}

Tahap preprocessing selanjutnya yang dilakukan adalah proses stemming, setiap token kata yang berimbuhan akan diubah menjadi bentuk kata dasar, sehingga meminimalisir dimensi kata yang terbentuk. Pada penelitian ini, untuk metode stemming Bahasa Indonesia yang digunakan adalah metode Arifin Setiono. Metode tersebut dipilih karena dalam penelitian Dian Novitasari mendapatkan kesimpulan bahwa proses stemming dokumen teks berbahasa Indonesia menggunakan metode Arifin \& Setiono memiliki presisi lebih tinggi sebesar 95\% dibandingkan dengan stemming menggunakan metode Porter yang menghasilkan sebesar 90\% [40]. Dalam metode tersebut mengasumsikan bahwa setiap kata masukan memiliki dua awalan (prefiks) dan tiga akhiran (sufiks). Berikut detail dari asumsi dari metode Arifin Setiono: 
[AK1]

$[A W 1]+[A W 2]+K D+[A K 3]+[A K 2]+$

Dimana AW merupakan awalan, KD merupakan kata dasar dan AK merupakan akhiran. Tahapan yang dilakukan pada metode tersebut adalah sebagai berikut [41]:

a. Melakukan pemeriksaan pada kamus kata dasar, jika terdapat kata yang sesuai pada kamus kata dasar maka proses cukup samapai disini, jika tidak akan dilanjutkan dengan mempersiapkan variabel awalan[0], awalan[1], akhiran[0] , akhiran[1] , akhiran[2] untuk menampung imbuhan yang telah terpisah dari kata dasar.

b. Pemotangan dilakukan secara berurutan sebagai berikut:

1) AW I, hasil disimpan pada awalan[0].

2) AW II, hasil disimpan pada awalan[1].

3) AK I, hasil disimpan pada akhiran[0].

4) AK II, hasil disimpan pada akhiran[1].

5) AK III, hasil disimpan pada akhiran[2].

Dalam setiap proses pemotongan di atas selalu dilakukan pemeriksaan dengan kamus kata dasar. Hal tersebut dilakukan untuk mengetahui apakah hasil pemotongan tersebut sudah ada dalam bentuk kata dasar. Apabila sudah dalam bentuk kata dasar, maka proses dinyatakan selesai dan tidak perlu melanjutkan proses pemotongan selanjutnya.

c. Namun jika sampai tahap dua belum menemukan kata dasar, maka akan dilakukan proses kombinasi. Kata dasar yang telah dihasilkan akan dikombinasikan dengan imbuhanimbuhan dalam 12 konfigurasi berikut:

a. $\mathrm{KD}$

b. $K D+A K I I I$

c. $K D+A K I I I+A K I I$

d. $K D+A K I I I+A K I I+A K I$

e. $A W I+A W I I+K D$

f. $A W I+A W I I+K D+A K I I I$

g. $A W I+A W \|+K D+A K I I I+A K I I$

h. $A W I+A W I I+K D+A K I I I+A K I I+$ AK I

i. $\quad A W I I+K D$

j. $\quad A W \|+K D+A K I I I$

k. $A W \|+K D+A K I I I+A K I I$

I. $A W I I+K D+A K I I I+A K I I+A K I$

Pemeriksaan dalam 12 kombinasi di atas selalu dilakukan pemeriksaan dengan kamus kata dasar. Hal tersebut dilakukan untuk mengetahui apakah hasil pemotongan tersebut sudah ada dalam bentuk kata dasar.
Apabila sudah dalam bentuk kata dasar, maka proses dinyatakan selesai, namun jika sampai pada tahap akhir tidak ditemukan kata dasar yang tepat maka akan dikembalikan pada kata semula.

Dalam kasus ini terdapat token kata "tempatnya", kata tersebut akan diubah menjadi kata dasar. Tahapan awal yang dilakukan adalah melakukan pemeriksaan dengan kamus kata dasar, namun karena kata "tempatnya" tidak ada dalam kamus kata dasar maka masuk pada tahap pemotongan.

Tahap pemotongan dilakukan dengan 5 urutan, setiap tahapan memiliki kamusnya masing-masing untuk menentukan imbuhan yang tepat pada kata tersebut. Berikut dibawah ini daftar imbuhan di setiap tahapan yang bisa dilihat pada Tabel 7

Tabel 7. Hasil Stemming

\begin{tabular}{|l|l|l|}
\hline No & Isi Kalimat & Hasil Stemming \\
\hline 1 & senang & senang \\
& banget & banget \\
& saya & saya \\
& dengan & dengan \\
& covid19 & covid19 \\
ini & ini \\
& jadi & jadi \\
& semakin & semakin \\
& banyak & banyak \\
& waktu & waktu \\
& dengan & dengan \\
& keluarga & keluarga \\
& tidak & tidak \\
& sibuk & sibuk \\
& dengan & dengan \\
& urusan & urusan \\
& masing & masing \\
& masing & masing \\
& & \\
\hline 2 & coba & coba \\
& kalian & kalian \\
& bayangkan & bayang \\
ibu & ibu \\
& melahirkan & lahir \\
& disuruh & suruh \\
& rapid & rapid \\
dulu, & dulu, \\
keburu & keburu \\
anaknya & anak \\
& tidak & tidak \\
selamat & selamat \\
& & \\
\hline
\end{tabular}




\section{Convert Negasi}

Tahapan ini adalah proses konversi kata kata negatif pada sebuah postingan mengenai covid19. Kata negasi dapat merubah makna sentiment suatu dokumen, sehingga kata negasi akan digabungkan dengan kata selanjutnya. Contoh kata negasi "tidak", "bukan", "jangan" dan sebagainya. Berikut merupakan proses Convert Negasi.

\begin{tabular}{|c|c|c|}
\hline No & Isi Kalimat & Hasil \\
\hline 1 & $\begin{array}{l}\text { senang } \\
\text { banget } \\
\text { saya } \\
\text { dengan } \\
\text { covid19 } \\
\text { ini } \\
\text { jadi } \\
\text { semakin } \\
\text { banyak } \\
\text { waktu } \\
\text { dengan } \\
\text { keluarga } \\
\text { tidak } \\
\text { sibuk } \\
\text { dengan } \\
\text { urusan } \\
\text { masing } \\
\text { masing }\end{array}$ & $\begin{array}{l}\text { senang } \\
\text { banget } \\
\text { saya } \\
\text { dengan } \\
\text { covid19 } \\
\text { ini } \\
\text { jadi } \\
\text { semakin } \\
\text { banyak } \\
\text { waktu } \\
\text { dengan } \\
\text { keluarga } \\
\text { tidaksibuk } \\
\text { dengan } \\
\text { urusan } \\
\text { masing } \\
\text { masing }\end{array}$ \\
\hline 2 & $\begin{array}{l}\text { coba } \\
\text { kalian } \\
\text { bayang } \\
\text { ibu } \\
\text { lahir } \\
\text { suruh } \\
\text { rapid } \\
\text { dulu, } \\
\text { keburu } \\
\text { anak } \\
\text { tidak } \\
\text { selamat }\end{array}$ & $\begin{array}{l}\text { coba } \\
\text { kalian } \\
\text { bayang } \\
\text { ibu } \\
\text { lahir } \\
\text { suruh } \\
\text { rapid } \\
\text { dulu, } \\
\text { keburu } \\
\text { anak } \\
\text { tidakselamat }\end{array}$ \\
\hline
\end{tabular}

\section{Stopword removal}

Setelah melewati tahap stemming, tahapan selanjutnya hasil dari proses stemming akan melalui proses Stopword removal. Proses Stopword removal pada penelitian ini adalah penghilangan kata yang terdapat list stopword seperti pada Lampiran A1. Kata "stopword" biasanya merujuk pada kata-kata yang paling umum seperti kata "dan", "dengan", "di", dan lainlain. Proses Stopword removal dapat dilihat pada Gambar 4.

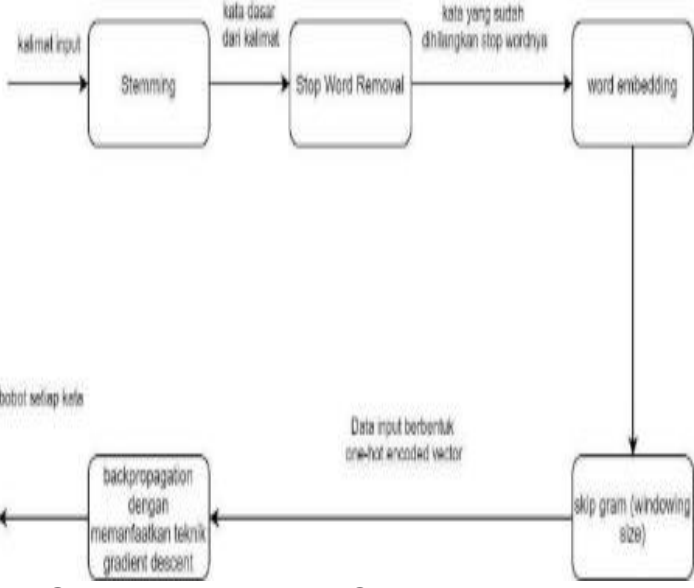

Gambar 4. Proses Stopword removal

Setelah melalui proses Stopword removal kalimat tidak mengandung kata stopword yang dapat membuat dimensi kamus kata menjadi besar. Hasil dari proses Stopword removal dapat dilihat pada Tabel 9.

Tabel 9. Hasil Stopword removal

\begin{tabular}{|c|c|c|}
\hline No & Isi Kalimat & $\begin{array}{l}\text { Hasil } \\
\text { Stopword } \\
\text { removal }\end{array}$ \\
\hline 1 & $\begin{array}{l}\text { senang } \\
\text { banget } \\
\text { saya } \\
\text { dengan } \\
\text { covid19 } \\
\text { ini } \\
\text { jadi } \\
\text { semakin } \\
\text { banyak } \\
\text { waktu } \\
\text { dengan } \\
\text { keluarga } \\
\text { tidaksibuk } \\
\text { dengan } \\
\text { urusan } \\
\text { masing } \\
\text { masing }\end{array}$ & $\begin{array}{l}\text { senang } \\
\text { banget } \\
\text { saya } \\
\text { dengan } \\
\text { covid19 } \\
\text { semakin } \\
\text { banyak } \\
\text { waktu } \\
\text { keluarga } \\
\text { tidaksibuk } \\
\text { urusan } \\
\text { masing } \\
\text { masing }\end{array}$ \\
\hline 2 & $\begin{array}{l}\text { coba } \\
\text { kalian } \\
\text { bayang } \\
\text { ibu } \\
\text { lahir } \\
\text { suruh } \\
\text { rapid } \\
\text { dulu, } \\
\text { keburu } \\
\text { anak } \\
\text { tidakselamat }\end{array}$ & $\begin{array}{l}\text { coba } \\
\text { bayang } \\
\text { ibu } \\
\text { lahir } \\
\text { suruh } \\
\text { rapid } \\
\text { dulu, } \\
\text { keburu } \\
\text { anak } \\
\text { tidakselamat }\end{array}$ \\
\hline
\end{tabular}


7. TF-idf

Secara sederhana, TF-idf adalah proses konversi sebuat teks menjadi angka, hal tersebut dilakukan karena Machine Learning dan arsitektur deep learning tidak mampu melakukan proses analisis pada input data berupa strings atau teks, sehingga membutuhkan angka sebagai input. Adapun proses TF-idf pada penelitian ini sebagai berikut:

a. Data:

\begin{tabular}{|c|}
\multicolumn{1}{c|}{ Tabel 10. Data } \\
\hline Word \\
\hline seneng \\
banget \\
saya \\
dengan \\
covid19 \\
ini \\
jadi \\
semakin \\
banyak \\
waktu \\
dengan \\
keluarga \\
tidaksibuk \\
dengan \\
urusan \\
masing \\
masing
\end{tabular}

Dari kata tersebut akan dilakukan metode one-hot encoding yang akan menghasilkan vektor dimana 1 merepresentasikan posisi kata tersebut berada, dan 0 untuk kata lainnya. Vektor representasi dari kata "seneng" mengacu pada format kata diatas adalah $1,0,0,0,0,0,0,0,0,0,0,0,0,0,0,0]$. Berikut merupakan one-hot encoding dari semua kata. Proses selanjutnya adalah menambahkan padding angka 0 pada akhir kalimat karena panjang setiap input kalimat bisa berbeda - beda. Pada tahap training data, input yang sudah melalui preprocessing akan dimasukkan ke dalam model.
Tabel 11. one-hot encoding

\begin{tabular}{|c|c|c|}
\hline No & Word & one-hot encoding \\
\hline 1 & $\begin{array}{l}\text { seneng } \\
\text { banget } \\
\text { saya } \\
\text { dengan } \\
\text { covid19 } \\
\text { ini } \\
\text { jadi } \\
\text { semakin } \\
\text { banyak } \\
\text { waktu } \\
\text { dengan } \\
\text { keluarga } \\
\text { tidaksibuk } \\
\text { dengan } \\
\text { urusan } \\
\text { masing } \\
\text { masing }\end{array}$ & $\begin{array}{l}1,0,0,0,0,0,0,0,0,0,0,0,0, \\
0,0,0,0,0 \\
0,1,0,0,0,0,0,0,0,0,0,0,0, \\
0,0,0,0,0 \\
0,0,1,0,0,0,0,0,0,0,0,0,0, \\
0,0,0,0,0 \\
0,0,0,1,0,0,0,0,0,0,0,0,0, \\
0,0,0,0,0 \\
0,0,0,0,1,0,0,0,0,0,0,0,0, \\
0,0,0,0,0 \\
0,0,0,0,0,1,0,0,0,0,0,0,0, \\
0,0,0,0,0 \\
0,0,0,0,0,0,1,0,0,0,0,0,0, \\
0,0,0,0,0 \\
0,0,0,0,0,0,0,1,0,0,0,0,0, \\
0,0,0,0,0 \\
0,0,0,0,0,0,0,0,1,0,0,0,0, \\
0,0,0,0,0 \\
0,0,0,0,0,0,0,0,0,1,0,0,0, \\
0,0,0,0,0 \\
0,0,0,0,0,0,0,0,0,0,1,0,0, \\
0,0,0,0,0 \\
0,0,0,0,0,0,0,0,0,0,0,1,0, \\
0,0,0,0,0 \\
0,0,0,0,0,0,0,0,0,0,0,0,1, \\
0,0,0,0,0 \\
0,0,0,0,0,0,0,0,0,0,0,0,0, \\
1,0,0,0,0 \\
0,0,0,0,0,0,0,0,0,0,0,0,0, \\
0,1,0,0,0 \\
0,0,0,0,0,0,0,0,0,0,0,0,0, \\
0,0,1,0,0 \\
0,0,0,0,0,0,0,0,0,0,0,0,0, \\
0,0,0,1,0 \\
0,0,0,0,0,0,0,0,0,0,0,0,0, \\
0,0,0,0,1\end{array}$ \\
\hline
\end{tabular}

b. Klasifikasi Menggunakan PNN

Tahap utama dari penelitian ini adalah klasifikasi dengan menggunakan algoritma Probabilistic Neural network. Fitur yang sudah dipilih sebelumnya akan digunakan sebagai masukan perhitungan oleh Probabilistic Neural network, untuk mengklasifikasikan dokumen. Pada tahap ini digunakan dokumen training sebagai dokumen masukan. Algoritma pada Probabilistic Neural network adalah sebagai berikut. 


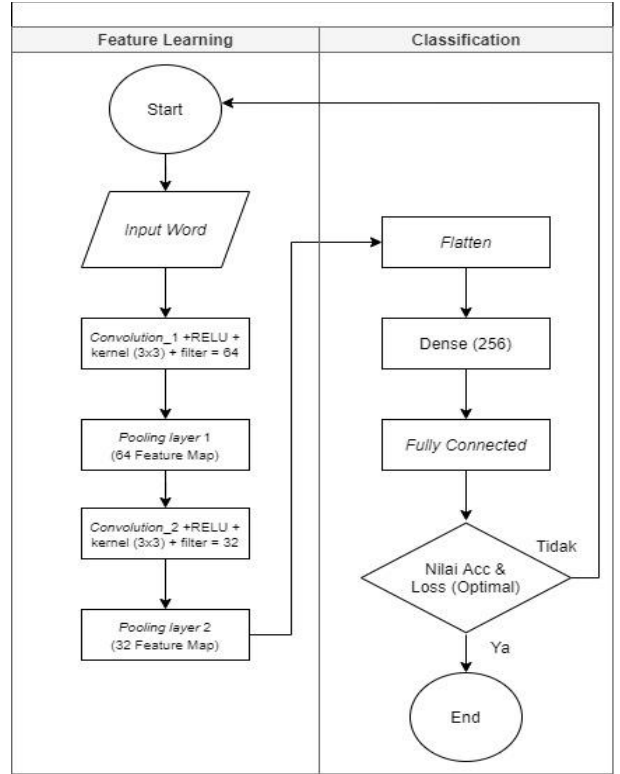

Gambar 5. FlowChart Model

1) Inisialisasi nilai awal pada filter pada lapisan konvolusi dan bobot pada lapisan fully connected dengan nilai acak, dan bisa dengan nilai awal 0 .

2) Melakukan proses konvolusi text masukan sesuai dengan filter pada lapisan konvolusi. Proses konvolusi dilakukan sesuai dengan persamaan

3) Feature maps yang didapatkan akan dikurangi ukurannya untuk mengurangi kompleksitas perhitungan pada lapisan selanjutnya.

Proses ini dilakukan pada 40 lapisan subsampling. Proses subsampling dengan menggunakan max pooling, atau meloloskan nilai tertinggi dari Feature maps yang ada dalam sebuah jendela subsampling.

4) Hasil dari lapisan subsampling merupakan Feature maps yang telah direduksi ukurannya, jika pada struktur lapisan PNN yang digunakan terdapat lapisan konvolusi setelah lapisan subsampling, maka tahapan selanjutnya adalah sama dengan tahap 1-3, jika tidak maka lanjutkan ke tahap 5 .

5) Feature maps yang didapat dari lapisan subsampling terakhir merupakan Feature maps yang akan digunakan pada lapisan fully connected sebagai fitur untuk melakukan klasifikasi. Feature maps yang berupa matriks akan diuraikan menjadi vector yang panjang.
Proses ini disebut vectorization and concatenation yang dinotasikan pada persamaan (3.24). Fitur yang masuk ke dalam lapisan fully connected $(f)$ merupakan hasil proses vektorisasi $((x))$ dari hasil subsampling pada lapisan sebelumnya ( $S p 1$ ), proses ini menggabungkan seluruh $n$ buah Feature maps.

6) Selanjutnya adalah proses perhitungan klasifikasi target dari fitur yang masuk ke dalam lapisan fully connected. Nilai klasifikasi kelas $((i))$ ini dilakukan dengan melakukan perhitungan menggunakan persamaan

Perhitungan pada persamaan ini menggunakan fitur dari lapisan subsampling sebelumnya $((j))$ yang dikalikan dengan bobot yang terkoneksi $((i)$,$) dan ditambahkan$ dengan bias $((i)) . \quad \hat{y}(i)=\sigma(\Sigma$ $W(i, j) f(j)+b(i) n j=1)$

7) Untuk mengetahui seberapa baik proses pembelajaran telah dilakukan, maka nilai Loss dihitung dengan persamaan.

Teks dari setiap kalimat tentang covid terlebih dahulu ditransformasikan ke dalam representasi vektor kata menggunakan TFidf kemudian dimasukkan ke input layer. Maksimum panjang sekuens dari input adalah 1000, sehingga input akan berupa matriks berukuran $1000 \times 300$. Adapun gambaran inputan pada proses PNN sebagai berikut:

Tabel 12. Proses PNN

\begin{tabular}{|l|l|l|}
\hline Kata & Tahap TF-idf & $\begin{array}{l}\text { Inputan ke } \\
\text { PNN }\end{array}$ \\
\hline seneng & Maksimum & matriks \\
banget & panjang & berukuran \\
saya & sekuens dari & 1000 x 300 \\
dengan & input adalah & \\
covid19 & 1000 & \\
ini & & \\
jadi & & \\
semakin \\
banyak & & \\
waktu \\
dengan & & \\
keluarga & & \\
tidaksibuk & & \\
dengan & & \\
urusan & & \\
masing & & \\
masing & & \\
\hline
\end{tabular}


a) Menentukan Model Network.

Probabilistic Neural network bekerja dengan cara memberikan layer. layers tersebut berupa layer input yang berisi word yang telah dilakukan praprocess. pada layer input akan ditentukan jumlah dense atau node. setelah word diinput di layer, maka terdapat dropout yang berfungsi menghilangkan kata yang tidak sesuai dan hanya kata yang sesuai yang dimasukan ke layer berikutnya yang disebut hidden layer. setelah difilter oleh beberapa leyers, maka digunakan Activation maps untuk mengeluarkan bobot dari setiap layer atau kata. bobot tersebut akan menghasilkan tiga class yaitu class positif, negatif dan netral. berikut merupakan rancangan model network pada Gambar 6.

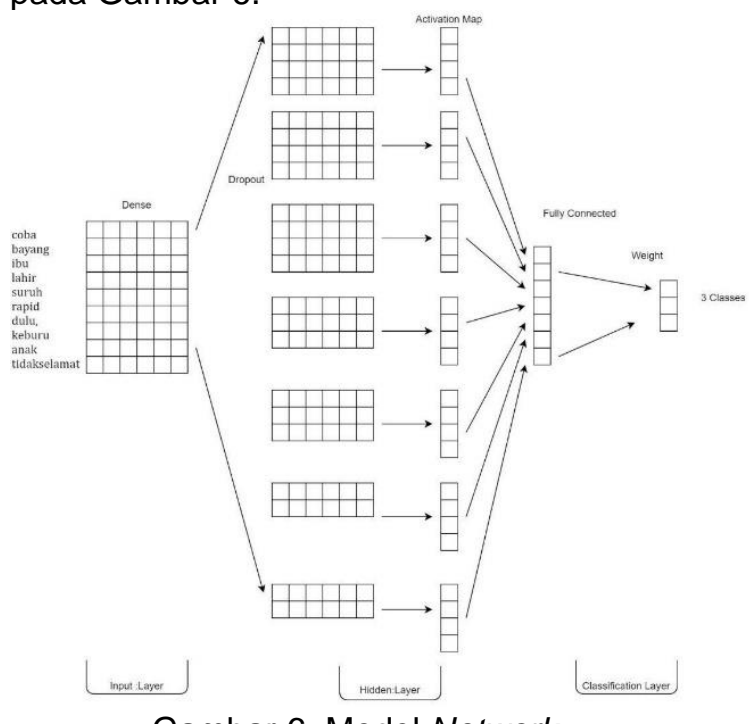

Gambar 6. Model Network

b) Perhitungan

Forward

Backpropagation menggunakan Softmax Activation

Tabel 13. Forward Backpropagation

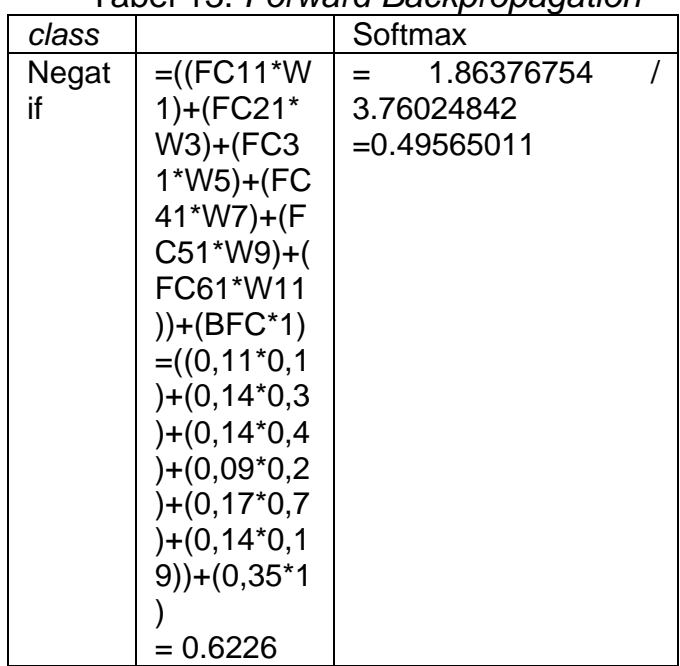

\begin{tabular}{|c|c|c|c|}
\hline Positif & $\begin{array}{l}=\left(\left(\mathrm{FC} 11^{*} \mathrm{~W}\right.\right. \\
2)+\left(\mathrm{FC} 21^{*}\right. \\
\mathrm{W} 4)+(\mathrm{FC} 3 \\
\left.1^{*} \mathrm{~W} 6\right)+(\mathrm{FC} \\
\left.41^{*} \mathrm{~W} 8\right)+(\mathrm{F} \\
\left.\mathrm{C} 51^{*} \mathrm{~W} 10\right) \\
+\left(\mathrm{FC} 61^{\star} \mathrm{W}\right. \\
12))+\left(\mathrm{BFC}{ }^{*}\right. \\
1) \\
=\left(\left(0,11^{*} 0,3\right.\right. \\
)+\left(0,14^{*} 0,4\right. \\
)+\left(0,14^{*} 0,3\right. \\
)+\left(0,09^{*} 0,1\right. \\
)+\left(0,17^{*} 0,8\right. \\
)+\left(0,14^{*} 0,1\right. \\
))+\left(0,35^{*} 1\right) \\
=0.64\end{array}$ & $\begin{array}{l}=1.89648088 \\
3.76024842 \\
=0.50434989\end{array}$ & 1 \\
\hline Netral & $\begin{array}{l}=\left(\left(\mathrm{FC} 11^{*} \mathrm{~W}\right.\right. \\
2)+\left(\mathrm{FC} 21^{*}\right. \\
\mathrm{W} 4)+(\mathrm{FC} 3 \\
\left.1^{*} \mathrm{~W} 6\right)+(\mathrm{FC} \\
\left.41^{*} \mathrm{~W} 8\right)+(\mathrm{F} \\
\left.\mathrm{C} 51^{*} \mathrm{~W} 10\right) \\
+\left(\mathrm{FC} 61^{\star} \mathrm{W}\right. \\
12))+\left(\mathrm{BFC} \mathrm{C}^{*}\right. \\
1) \\
=\left(\left(0,11^{*} 0,4\right.\right. \\
)+\left(0,14^{*} 0,1\right. \\
)+\left(0,14^{*} 0,3\right. \\
)+\left(0,09^{*} 0,1\right. \\
)+\left(0,17^{*} 0,8\right. \\
)+\left(0,14^{*} 0,1\right. \\
))+\left(0,35^{\star} 1\right) \\
=0.69\end{array}$ & $\begin{array}{l}=1.99648088 \\
3.76024842 \\
=0.59234977\end{array}$ & 1 \\
\hline
\end{tabular}

8. Pengujian

Perbandingan dengan Metode Klasifikasi yang Lain Uji coba berikut dilakukan untuk membandingkan unjuk kerja desain PNN (sebagai desain PNN terbaik yang sudah terbukti) dengan metode klasifikasi yang lain, yaitu k-Neural network $(\mathrm{k}-\mathrm{NN})$ dan SVM. Untuk k-NN, dataset text mode diuji coba dengan menggunakan parameter $\mathrm{k}$ sebesar 5 . Sedangkan pada metode SVM, dataset diuji coba menggunakan linear kernel. Pengujian dilakukan untuk Rika Rokhana: Probabilistic Neural network untuk ... ISSN 2301 - 415665 JNTETI, Vol. 8, No. 1, Februari 2019 mengklasifikasi text dalam kelas positif, negatif dan netral. Data masukan untuk classifier k-NN dan SVM adalah bobot nilsi pada dataset. Hasil pengujian disajikan dalam Tabel 14. 
Tabel 14. Perbandingan dengan Metode

\begin{tabular}{|l|l|l|l|}
\hline No & $\begin{array}{l}\text { Jumlah } \\
\text { dataset }\end{array}$ & Metode & Akurasi \\
\hline 1 & 400 & SVM & $70 \%$ \\
\hline 2 & 1100 & KNN & $76 \%$ \\
\hline 3 & 1177 & PNN & $86 \%$ \\
\hline
\end{tabular}

9. Pengujian Performansi

Tahap pengujian nilai akurasi dari metode yang digunakan pada penelitian ini dilakukan menggunakan metode hold-out dengan menggunakan 50 data sebagai data latih. Proses klasifikasi ini menggunakan kombinasi nilai parameter yaitu parameter cost (C). Adapun masing-masing nilai parameter yang digunakan diantaranya adalah $C=(0.1,0.5,0.75,1,10,100)$. Berikut adalah hasil dari pengujian performansi menggunakan parameter yang telah disebutkan.

Confussion matrix dan hasil pengujian dengan parameter cost $=0.1$ dapat dilihat pada Tabel 15

Tabel 15. Confussion matrix pengujian parameter $\mathrm{C}=0.1$

\begin{tabular}{|c|c|c|c|}
\hline \multirow{2}{*}{ Aktual } & \multicolumn{3}{|c|}{ Kelas Hasil Klasifikasi } \\
\hline & Positif & Negatif & Netral \\
\hline Positif & 15 & 19 & 5 \\
\hline Negatif & 4 & 10 & 2 \\
\hline Netral & 3 & 3 & 13 \\
\hline \multicolumn{4}{|c|}{ Akurasi $=\frac{T P+T N}{T P+F P+F N+T N}$} \\
\hline & $\begin{array}{l}+4+5 \\
\operatorname{urgsi}\end{array}$ & $\begin{array}{l}+4+10+ \\
\frac{39}{50}=78 \%\end{array}$ & \\
\hline
\end{tabular}

Tabel 16. hasil akurasi pengujian $C=0.1$

\begin{tabular}{|l|l|l|}
\hline No & C & $\begin{array}{l}\text { Nilai } \\
\text { Akurasi } \\
\text { PNN }\end{array}$ \\
\hline 1 & 0.1 & $78 \%$ \\
\hline
\end{tabular}

Berdasarkan pengujian pertama, didapatkan nilai akurasi sebesar $78 \%$.

\section{Kesimpulan}

Berdasarkan penelitian dan hasil pengujian yang telah dilakukan, dapat ditarik beberapa kesimpulan sebagai berikut :
1. Adanya penelitian ini berhasil melakukan sentiment analysis sehingga opini mengenai covid19 di social media pada kehidupan sehari-hari menjadi lebin jelas.

2. Penelitian ini menghasilkan akurasi sebesar $86 \%$ dimana akurasi ini lebih baik dibandingkan dengan penelitian sebelumnya yang melakukan penelitian dengan $76 \%$. Hal ini dikarenakan dataset yang lebih banyak dan praprocess yang lebih lengkap.

\section{Referensi}

Amelia, N. (2020). No Title. Unair News. http://news.unair.ac.id/2020/01/31/men genal-perkembangan-jenis-baru-viruscorona-yang-infeksi-ribuan-orang/

Cahyadi, R., Damayanti, A., \& Aryadani, D. (2020). Recurrent neural network (rnn) dengan long short term memory (Istm) untuk analisis sentimen data instagram. $5,1-9$.

Faturohman, F., Irawan, B., Setianingsih, C., Elektro, F. T., \& Telkom, U. (2020). ANALISIS SENTIMEN PADA BPJS KESEHATAN MENGGUNAKAN RECURRENT NEURAL NETWORK SENTIMENT ANALYSIS ON BPJS KESEHATAN USING RECURRENT NEURAL. 7(2), 4545-4552.

Kasmad. (2020). Covid 19 dan Penyebarannya.

Khatami, F. A., Irawan, B., Si, S., \& Setianingsih, C. (2020). ANALISIS SENTIMEN TERHADAP REVIEW APLIKASI LAYANAN E-COMMERCE MENGGUNAKAN METODE CONVOLUTIONAL NEURAL NETWORK SENTIMENT ANALYSIS OF E-COMMERCE APPLICATION REVIEWS USING THE CONVOLUTIONAL NEURAL NETWORK METHOD. 7(2), 45594566.

Mardiana, T., Syahreva, H., Informasi, S., Bina, U., \& Informatika, S. (2019). KOMPARASI METODE KLASIFIKASI PADA ANALISIS SENTIMEN USAHA. 15(2), 267-274. https://doi.org/10.33480/pilar.v15i2.752

Nemes, L., \& Kiss, A. (2021). Social media sentiment analysis based on COVID19. Journal of Information and Telecommunication, 5(1), 1-15. https://doi.org/10.1080/24751839.2020 .1790793

Pertiwi, Wi. M. (2019). ANALISIS SENTIMEN OPINI PUBLIK MENGENAI SARANA DAN TRANSPORTASI MUDIK TAHUN 
2019 PADA TWITTER MENGGUNAKAN ALGORITMA NAÏVE BAYES, NEURAL NETWORK, KNN DAN SVM. 14(1), 27-32.

Samsir, Ambiyar, Verawardina, U., Edi, F., \& Watrianthos, R. (2021). Analisis Sentimen Pembelajaran Daring Pada Twitter di Masa Pandemi COVID-19 Menggunakan Metode Naïve Bayes. Jurnal Media Informatika Budidarma, 5, 157-163.

https://doi.org/10.30865/mib.v5i1.2604

Zulfa, I., \& Winarko, E. (2017). Sentimen Analisis Tweet Berbahasa Indonesia Dengan Deep Belief Network. IJCCS (Indonesian Journal of Computing and Cybernetics Systems), 11(2), 187. https://doi.org/10.22146/ijccs.24716 